\title{
PROPAGATION OF GARDENIA ROOT STOCK Gardenia thunbergia L.F. By Stem Cuttings
}

\author{
A. O. Al-Atrakchii \\ G. Y. Q. Saleh
}

Hort. and landscape design Dept., College of Agric. and Forestry, Mosul Univ., Iraq

\begin{abstract}
This study was conducted in greenhouse of Department of Horticulture and Landscape Design, College of Agriculture and Forestry, Mosul University. The aim of this work is to study the effect of two planting dates, December and March after treated the cuttings with IBA+NAA mixture at 0+0 (control), $1000+1000$ and $2000+1000 \mathrm{mg} . \mathrm{l}^{-1}$ in quick-dip method for 10 seconds, in addition to wounding the cuttings base or without. The results of this investigation were showed that planting date had a great effect on rooting ability, planting cuttings in March gave higher rooting percentage 58.89\%, and best results of all rooting characters studied. Wounded cuttings gave higher values of rooting percentage $58.11 \%$ and all other characters. On the other hand, cuttings treated with IBA+NAA mixture at $2000+1000 \mathrm{mg} \cdot \mathrm{l}^{-1}$ gave $58.33 \%$ rooting percentage, 3.91 roots per cutting, longest root length $7.98 \mathrm{~cm}$, 1.58 shoots number and $1.25 \mathrm{~cm}$ shoot length. In general, wounding apical cuttings taken in March and treated with $2000+1000 \mathrm{mg}^{-1}{ }^{-1}$ IBA+NAA mixture proved most effective treatment in rooted Gardenia thunbergia cuttings.
\end{abstract}

\section{INTRODUCTION}

The plant which widespread in Iraqian gardens was Cap-Jasmine Gardenia jasminoides (Albaili, 1967), that made a great foundation in Landscape, with glossy, dark green foliage. It was effectively used as either focus or background in the informal plantings and for tropical-theme landscape plantings. The plants do well in containers and suitable as well for hedges, low screens, mass plantings and ground covers. On the other hand, gardenia was a popular cut flower for the florist for use in corsage and flower arrangement (Ruppert and Bradshaw, 1994).

Cape-jasmine faced many problems when cultured on root system, a root-knot nematodes were a major problem which caused a poor growth, shunted, chlorotic foliage, flower premature welting, low vigor and leaf or bloom loss in a mild stress (Kobayashi and Kaufman, 2006). But Mastalerz (1977) stated other problem, that low substrate temperature may reduce mineral absorption, thus an intervinal chlorosis occurs in the leaves of gardenias at substrate temperature below $19^{\circ} \mathrm{c}$ for two weeks. The symptoms that develop most extensively in the young leaves were characteristics of an iron deficiency, because of the lack the ability to absorb iron ions. To solve that problems $G$. jasminoides grafted on G. thunbergia, this species was valuable due to its nematodes resistance, the vigor it imparts to species grafted on its roots and able to absorb iron ions at low temperatures.

G. thunbergia was an evergreen shrub, $3 \mathrm{~m}$ height, leaves elliptic, flowers wax, very fragrant, remain for one day. This species used only as a rootstock 
for G. Jasminoides (Bailey, 1969). Gardenia rootstock G. thunbergia propagated by seeds, when seedlings about $15 \mathrm{~cm}$ long or taller with stem diameter about the thickness of pencil they are ready to be grafted (Bradshaw, 2003).

Received on 23/3/2008 Accepted 17/4/2008

Many investigators emphasized that the time of the year have a dramatic influence on rooting cuttings, with many plant species there is an optimal period of the year for rooting, thus by rooting cuttings during optimal periods were maximized the rooting process and speed up the production liners (Anand and Heberlein, 1975). Zarad and Saleh (1994) found that planting Coffea arabica cuttings in April gave significantly best results of rooting percentage $65.1 \%$ when treated with IBA at $2000 \mathrm{mg}^{-1} \mathrm{l}^{-1}$ compared with $40.8 \%$ in October. On the other physiological study Souidan et al. (1995) pointed to best planting date of Ficus elastica var. decora cuttings was February and March which coincided with higher content of total soluble sugars and phenolic compounds in buds and stems extract during the period from October to August.

Rooting hormones are very necessary for easy to root and difficult to root plants for its role in improve the quality of root system developed, decrease rooting time and improve the percentage of cutting rooted (Salman 1988), countless studies have been done proving effectiveness of auxin treatment of cuttings. Both herbaceous and woody plants benefit from rooting hormone treatment. Even easy-to-root species may benefit from rooting hormones, in that the adventitious root produced will be hasten root initiation, increase the number and quality of roots and increase uniformity of rooting (Hartmann et al. 2002). In contrast, too much rooting hormone can hinder root growth, so care has been taken to find the right concentration to use (Ruchala, 2002). There are now several commercial synthetic forms of rooting hormones for nursery industry. These typically include IBA or NAA or a mixture of both (Blazich, 1988).

Hartmann, et al.(2002) recommended to propagated G. jasminoides by leafy terminal cuttings treated with $3000 \mathrm{mg} \cdot \mathrm{l}^{-1}$ of IBA. (Indole butyric acid), and rooted under mist from spring to fall. Blythe et al. (2004) found that two node cutting of $G$. jasminoides "Radicans" treated with $4920 \mu \mathrm{mIBA}+2685 \mu \mathrm{M}$ NAA as a quick-dip method prior to insert into the substrate produced 9.1 roots/cuttings and total root length $311 \mathrm{~mm}$, compared with 5.2 roots/cutting and total roots length $66 \mathrm{~mm}$ for untreated cuttings.

Wounding cuttings base is a common practice in commercial production of rooted cuttings. Wells (1962) stated that wounding was used for: first, to speed up the rooting processes, second, to increase the number and quality of roots, and third, to improve attachment points between roots and the cuttings. Al-Atrakchii (1998) indicated that Syringa vulgaris cuttings, rooting percentage increased by wounding the cuttings and furthermore, enhanced good root characters. Al-Noaimy (1999) found by wounding the terminal cuttings of 
Cotoneaster prostrate taken at November to March (except those taken at December) treated with a mixture of IBA and NAA at concentration $1000 \mathrm{mg} . \mathrm{l}^{-}$ ${ }^{1}$ for both by quick-dip method gave the best result for rooting percentage $100 \%$, higher number of roots/cutting 12.08-23.05, in addition to enhancing vegetative growth.

The objectives of this study are to investigate the effect of planting dates, auxins concentrations and wounding on rooting ability of apical stem cuttings of

G. thunbergia.

\section{MATERIALS AND METHODS}

This experiments was carried out in the greenhouse of Horticulture and landscape Department/College of Agric and Forestry, to study the effect of three factors on rooting of $G$. thunbergia apical stem cuttings which include: planting dates (December and March ) auxins treatments with IBA and NAA mixture in mg. $1^{-1}$ (control, $1000+1000$ and 2000+1000) respectively by using a quick-dip method for 10 seconds, and the third was wounding treatments, half of the cuttings wounded at the basal end ( 2 opposing longitudinal $1 \mathrm{~cm}$ length wound) and the second half cuttings left without wound.

Terminal hardwood cuttings of Gardenia thunbergia L.F. at length $6 \pm 2 \mathrm{~cm}$ were collected early morning at each planting dates, the wounding treatments of the cuttings were made by using surgery blade, all cuttings were dipped in the rooting hormones solutions and then the basal end treated with Benomyl $25 \%$ as powder. Cuttings were planted in coarse river sand media in propagation bed for 22 weeks which covered by transparent polyethylene. A Factorial Experiment (2 X 2 X 5) was conducted by Completely Randomized Block Design with 8 cuttings for each replicate in treatment. At the end of propagation period measurements were taken for rooting percentage $\%$, mean number of roots/cutting, mean length of longest root $(\mathrm{cm})$, mean number and length of shoots/cutting. The statistical analysis was done by using SAS (1996) after angular conversion for rooting percentage data. Means comparison was done by Duncan's Multiple Ranges Test under probability 5\%.

\section{RESULTS AND DISCUSSION}

The results in Table (1) indicated that planting cuttings in March gave significantly best results of rooting percentage $58.89 \%$, roots number 4.53 , longest root length $9.23 \mathrm{~cm}$, shoots number and length $(1.79$ and $1.26 \mathrm{~cm}$, respectively), compared with values obtained from cuttings taken in December. As for the effect

Table(1): Effect of planting dates, wounding and auxins mixture concentrations on rooting ability of $G$. thunbergia cutting.

\begin{tabular}{|c|c|c|c|c|c|}
\hline Treatments & $\begin{array}{c}\text { Rooting } \\
\text { percentage } \\
(\%)\end{array}$ & $\begin{array}{c}\text { Root } \\
\text { number }\end{array}$ & $\begin{array}{c}\text { Root length } \\
(\mathrm{cm})\end{array}$ & $\begin{array}{c}\text { Shoots } \\
\text { number }\end{array}$ & $\begin{array}{c}\text { Shoots } \\
\text { length } \\
(\mathrm{cm})\end{array}$ \\
\hline \multicolumn{6}{|c|}{ Planting dates } \\
\hline Dec. & $32.22 \mathrm{~b}$ & $0.90 \mathrm{~b}$ & $2.32 \mathrm{~b}$ & $0.93 \mathrm{~b}$ & $0.45 \mathrm{~b}$ \\
\hline
\end{tabular}




\begin{tabular}{|c|c|c|c|c|c|}
\hline March & $58.89 \mathrm{a}$ & $4.53 \mathrm{a}$ & $9.23 \mathrm{a}$ & $1.79 \mathrm{a}$ & $1.26 \mathrm{a}$ \\
\hline \multicolumn{7}{|c|}{ Wounding treatments } \\
\hline Without & $39.99 \mathrm{~b}$ & $1.99 \mathrm{~b}$ & $3.43 \mathrm{~b}$ & $1.01 \mathrm{~b}$ & $0.60 \mathrm{~b}$ \\
Wounded & $51.11 \mathrm{a}$ & $3.44 \mathrm{a}$ & $8.12 \mathrm{a}$ & $1.71 \mathrm{a}$ & $1.10 \mathrm{a}$ \\
\hline \multicolumn{7}{|c|}{ IBA+NAA mixture $\left(\mathrm{mg.1}^{-1}\right)$} \\
\hline Control & $21.67 \mathrm{~b}$ & $1.42 \mathrm{c}$ & $2.12 \mathrm{~b}$ & $0.75 \mathrm{~b}$ & $0.61 \mathrm{~b}$ \\
$1000+1000$ & $56.67 \mathrm{a}$ & $2.82 \mathrm{~b}$ & $7.24 \mathrm{a}$ & $1.75 \mathrm{a}$ & $0.70 \mathrm{~b}$ \\
$2000+1000$ & $58.33 \mathrm{a}$ & $3.91 \mathrm{a}$ & $7.98 \mathrm{a}$ & $1.58 \mathrm{a}$ & $1.25 \mathrm{a}$ \\
\hline
\end{tabular}

Means with the same letters are not significantly different at 5\% level based on Duncan's Multiple Range Test.

of wounding, the data pointed to the cuttings wounded gave significantly best results of rooting percentage $51.11 \%$, roots number per cutting 3.44 , longest root length $8.12 \mathrm{~cm}$, shoots number 1.71 , and shoots length $1.10 \mathrm{~cm}$. On the other hand, cuttings treated with $1000+1000$ or $2000+1000 \mathrm{mg}^{-1}$ of IBA+NAA mixture enhanced all rooting characters significantly compared with control except shoots length when the cuttings treated with $1000+1000$ mg. $1^{-1}$ which didn't differ significantly from control.

The interaction effect between planting dates and wounding on rooting ability, showed that wounded cuttings planted in March gave significantly best results of rooting percentage $64.44 \%$, roots number 5.60 roots/cuttings, longest root length $13.14 \mathrm{~cm}$, number of shoots 2.31 and shoots length $1.72 \mathrm{~cm}$ compared with other treatments, except rooting percentage value recorded from cuttings without wounding planted in March (Table 2).

Table(2): The effect of planting dates and wounding on rooting ability of $G$. thunbergia cuttings.

\begin{tabular}{|c|c|c|c|c|c|c|}
\hline $\begin{array}{c}\text { Planting } \\
\text { dates }\end{array}$ & $\begin{array}{c}\text { Wounding } \\
\text { treatments }\end{array}$ & $\begin{array}{c}\text { Rooting } \\
\text { percentage } \\
(\%)\end{array}$ & $\begin{array}{c}\text { Roots } \\
\text { number }\end{array}$ & $\begin{array}{c}\text { Root } \\
\text { length } \\
(\mathrm{cm})\end{array}$ & $\begin{array}{c}\text { Shoots } \\
\text { number }\end{array}$ & $\begin{array}{c}\text { Shoots } \\
\text { length } \\
(\mathrm{cm})\end{array}$ \\
\hline \multirow{2}{*}{ Dec. } & Without & $26.67 \mathrm{c}$ & $0.51 \mathrm{c}$ & $1.53 \mathrm{~d}$ & $0.76 \mathrm{~b}$ & $0.14 \mathrm{~b}$ \\
\cline { 2 - 7 } & Wounded & $37.78 \mathrm{bc}$ & $1.28 \mathrm{c}$ & $3.11 \mathrm{c}$ & $1.11 \mathrm{~b}$ & $0.48 \mathrm{~b}$ \\
\hline \multirow{2}{*}{ March } & Without & $53.33 \mathrm{ab}$ & $3.46 \mathrm{~b}$ & $5.33 \mathrm{~b}$ & $1.27 \mathrm{~b}$ & $0.79 \mathrm{~b}$ \\
\cline { 2 - 7 } & wounded & $64.44 \mathrm{a}$ & $5.60 \mathrm{a}$ & $13.14 \mathrm{a}$ & $2.31 \mathrm{a}$ & $1.72 \mathrm{a}$ \\
\hline
\end{tabular}

Means with the same letters are not significantly different at $5 \%$ level based on Duncan's Multiple Range Test.

The data in Table(3) of the interaction effect between planting dates and auxins mixture concentrations on rooting ability, pointed to the significantly effect of treated the cuttings with $1000+1000$ and $2000+1000 \mathrm{mg}^{-1}{ }^{-1}$ of IBA+NAA mixture in March on all rooting characters studied compared with all other treatments except the values of roots number and shoots length when cutting treated with $1000+1000 \mathrm{mg} \cdot \mathrm{l}^{-1}$ of IBA+NAA mixture and planted in March, which decreased significantly from the higher values obtained.

Table (3): The effect of planting dates and auxins concentrations on rooting ability of $G$. thunbergia cuttings.

\begin{tabular}{|l|c|c|c|c|c|c|}
\hline Planting & IBA+NAA & Rooting & Roots & Root & Shoots & Shoots \\
\hline
\end{tabular}




\begin{tabular}{|c|c|c|c|c|c|c|}
\hline dates & $\begin{array}{c}\text { conc. } \\
\left(\mathrm{mg} .1^{-1}\right)\end{array}$ & $\begin{array}{c}\text { percentage } \\
(\%)\end{array}$ & number & $\begin{array}{c}\text { length } \\
(\mathrm{cm})\end{array}$ & number & $\begin{array}{c}\text { length } \\
(\mathrm{cm})\end{array}$ \\
\hline \multirow{3}{*}{ Dec. } & Control & $16.67 \mathrm{c}$ & $0.40 \mathrm{~d}$ & $0.83 \mathrm{c}$ & $0.53 \mathrm{~b}$ & $0.41 \mathrm{~b}$ \\
\cline { 2 - 7 } & $1000+1000$ & $43.33 \mathrm{~b}$ & $1.07 \mathrm{bc}$ & $2.98 \mathrm{bc}$ & $1.30 \mathrm{~b}$ & $0.43 \mathrm{~b}$ \\
\cline { 2 - 7 } & $2000+1000$ & $36.76 \mathrm{bc}$ & $1.23 \mathrm{bc}$ & $3.15 \mathrm{bc}$ & $0.97 \mathrm{~b}$ & $0.51 \mathrm{~b}$ \\
\hline \multirow{3}{*}{ March } & Control & $26.67 \mathrm{bc}$ & $2.43 \mathrm{c}$ & $3.40 \mathrm{~b}$ & $0.97 \mathrm{~b}$ & $0.82 \mathrm{~b}$ \\
\cline { 2 - 7 } & $1000+1000$ & $70.00 \mathrm{a}$ & $4.57 \mathrm{~b}$ & $11.50 \mathrm{a}$ & $2.20 \mathrm{a}$ & $0.97 \mathrm{~b}$ \\
\cline { 2 - 7 } & $2000+1000$ & $80.00 \mathrm{a}$ & $6.60 \mathrm{a}$ & $12.80 \mathrm{a}$ & $2.20 \mathrm{a}$ & $1.99 \mathrm{a}$ \\
\hline
\end{tabular}

Means with the same letters are not significantly different at 5\% level based on Duncan's Multiple Range Test.

The data in Table (4) indicated that the best results of rooting percentage obtained when cuttings wounded or without and treated with $1000+1000$ or 2000+1000 mg..$^{-1}$ IBA+NAA mixture. On the other hand. Higher values of roots number 4.49 , longest root length $10.97 \mathrm{~cm}$ and shoots length $1.57 \mathrm{~cm}$ obtained from wounded cuttings treated with $2000+1000 \mathrm{mg} \cdot \mathrm{l}^{-1} \mathrm{IBA}+\mathrm{NAA}$ mixture, while higher value of shoots number 2.26 obtained when wounded cuttings treated with $1000+1000 \mathrm{mg} \cdot \mathrm{l}^{-1}$ of IBA+NAA mixture. The significantly lowest values of all characters studied were recorded with control cuttings (without wounding and not treated with auxins).

Table (4): The effect of wounding and auxins concentrations on rooting ability of $G$. thunbergia cuttings.

\begin{tabular}{|c|c|c|c|c|c|c|}
\hline Wounding & $\begin{array}{c}\text { IBA+NAA } \\
\text { conc. } \\
\left(\mathrm{mg} . \mathrm{l}^{-1}\right)\end{array}$ & $\begin{array}{c}\text { Rooting } \\
\text { percentage } \\
(\%)\end{array}$ & $\begin{array}{c}\text { Roots } \\
\text { number }\end{array}$ & $\begin{array}{c}\text { Root } \\
\text { length } \\
(\mathrm{cm})\end{array}$ & $\begin{array}{c}\text { Shoots } \\
\text { number }\end{array}$ & $\begin{array}{c}\text { Shoots } \\
\text { length } \\
(\mathrm{cm})\end{array}$ \\
\hline \multirow{3}{*}{ Without } & Control & $20.00 \mathrm{~b}$ & $0.63 \mathrm{c}$ & $1.37 \mathrm{c}$ & $0.47 \mathrm{c}$ & $0.31 \mathrm{~b}$ \\
\cline { 2 - 7 } & $1000+1000$ & $64.67 \mathrm{a}$ & $2.30 \mathrm{bc}$ & $3.95 \mathrm{~b}$ & $1.23 \mathrm{bc}$ & $0.57 \mathrm{~b}$ \\
\cline { 2 - 7 } & $2000+1000$ & $53.33 \mathrm{a}$ & $3.03 \mathrm{ab}$ & $4.98 \mathrm{~b}$ & $1.33 \mathrm{a}-\mathrm{c}$ & $0.93 \mathrm{ab}$ \\
\hline \multirow{3}{*}{ wound } & Control & $23.33 \mathrm{~b}$ & $2.20 \mathrm{bc}$ & $2.87 \mathrm{bc}$ & $1.03 \mathrm{bc}$ & $0.92 \mathrm{ab}$ \\
\cline { 2 - 7 } & $1000+1000$ & $66.67 \mathrm{a}$ & $3.33 \mathrm{ab}$ & $10.03 \mathrm{a}$ & $2.26 \mathrm{a}$ & $0.82 \mathrm{ab}$ \\
\cline { 2 - 7 } & $2000+1000$ & $63.33 \mathrm{a}$ & $4.49 \mathrm{a}$ & $10.97 \mathrm{a}$ & $1.83 \mathrm{ab}$ & $1.57 \mathrm{a}$ \\
\hline
\end{tabular}

Means with the same letters are not significantly different at $5 \%$ level based on Duncan's Multiple Range Test.

The data in Table(5) of the interaction between planting dates, wounding and auxins mixture concentrations clearly indicated that the higher rooting percentage $86.67 \%$, root number 7.73 , shoots number 3.00 and length $2.74 \mathrm{~cm}$ obtained from

Table(5): The effect of planting dates, wounding and auxins concentrations on rooting ability of $G$. thunbergia cuttings.

\begin{tabular}{|c|c|c|c|c|c|c|c|}
\hline $\begin{array}{c}\text { Planting } \\
\text { dates }\end{array}$ & wounding & $\begin{array}{c}\text { IBA+NAA } \\
\text { conc. } \\
\left(\mathrm{mg} \cdot l^{-1}\right)\end{array}$ & $\begin{array}{l}\text { Rooting } \\
\text { percentage } \\
(\%)\end{array}$ & $\begin{array}{l}\text { Roots } \\
\text { number }\end{array}$ & $\begin{array}{l}\text { Root } \\
\text { length } \\
(\mathrm{cm})\end{array}$ & $\begin{array}{l}\text { Shoots } \\
\text { number }\end{array}$ & $\begin{array}{c}\text { Shoots } \\
\text { length } \\
(\mathrm{cm})\end{array}$ \\
\hline \multirow{4}{*}{ Dec. } & \multirow{3}{*}{ Without } & Control & $13.33 \mathrm{e}$ & $0.27 \mathrm{~d}$ & $0.60 \mathrm{~d}$ & $0.33 \mathrm{c}$ & $0.25 \mathrm{c}$ \\
\hline & & $1000+1000$ & $33.33 \mathrm{c}-\mathrm{e}$ & $0.67 \mathrm{~d}$ & $2.50 \mathrm{~cd}$ & $0.67 \mathrm{c}$ & $0.37 \mathrm{bc}$ \\
\hline & & $2000+1000$ & $33.33 \mathrm{c}-\mathrm{e}$ & $0.60 \mathrm{~d}$ & $1.50 \mathrm{~cd}$ & $1.27 \mathrm{bc}$ & $0.63 \mathrm{~b}$ \\
\hline & wound & Control & $20.00 \mathrm{e}$ & $0.53 \mathrm{~d}$ & $1.07 \mathrm{~cd}$ & $0.73 \mathrm{c}$ & $0.57 \mathrm{~b}$ \\
\hline
\end{tabular}




\begin{tabular}{|c|c|c|c|c|c|c|c|}
\hline & $1000+1000$ & $53.33 \mathrm{~b}-\mathrm{d}$ & $1.47 \mathrm{~d}$ & $3.45 \mathrm{~cd}$ & $1.92 \mathrm{a}-\mathrm{c}$ & $0.49 \mathrm{~b}$ \\
\hline & & $2000+1000$ & $40.00 \mathrm{c}-\mathrm{e}$ & $1.85 \mathrm{~cd}$ & $4.80 \mathrm{bc}$ & $0.67 \mathrm{c}$ & $0.39 \mathrm{bc}$ \\
\hline \multirow{4}{*}{ March } & Control & $26.67 \mathrm{~d} \mathrm{e}$ & $1.00 \mathrm{~d}$ & $2.13 \mathrm{~cd}$ & $0.60 \mathrm{c}$ & $0.37 \mathrm{bc}$ \\
\cline { 3 - 8 } & \multirow{3}{*}{ Without } & $1000+1000$ & $60.00 \mathrm{a}-\mathrm{c}$ & $3.93 \mathrm{bc}$ & $5.40 \mathrm{bc}$ & $1.80 \mathrm{a}-\mathrm{c}$ & $0.77 \mathrm{~b}$ \\
\hline & & $2000+1000$ & $73.33 \mathrm{ab}$ & $5.46 \mathrm{~b}$ & $8.46 \mathrm{~b}$ & $1.40 \mathrm{bc}$ & $1.23 \mathrm{~b}$ \\
\hline & \multirow{3}{*}{ wound } & Control & $26.67 \mathrm{de}$ & $3.87 \mathrm{bc}$ & $4.67 \mathrm{bc}$ & $1.33 \mathrm{bc}$ & $1.27 \mathrm{~b}$ \\
\hline & & $1000+1000$ & $80.00 \mathrm{ab}$ & $5.20 \mathrm{~b}$ & $17.60 \mathrm{a}$ & $2.60 \mathrm{ab}$ & $1.16 \mathrm{~b}$ \\
\hline & & $2000+1000$ & $86.67 \mathrm{a}$ & $7.73 \mathrm{a}$ & $17.15 \mathrm{a}$ & $3.00 \mathrm{a}$ & $2.74 \mathrm{a}$ \\
\hline
\end{tabular}

Means with the same letters for each factor are not significantly different at $5 \%$ level based on Duncan's multiple Range Test.

wounded cuttings planted in March after treated with $2000+1000 \mathrm{mg}^{-1} \mathrm{l}^{-1}$ of IBA+NAA mixture, except longest root length which gave 17.60 and $17.15 \mathrm{~cm}$ when wounded cuttings planted in March after treated with $1000+1000$ and 2000+1000 mg. $\mathrm{l}^{-1}$ of IBA+NAA mixture, respectively, these values decreased significantly to the lowest values when cuttings planted in December and not wounded interact with control.

The data in Table (1) showed that planting cuttings in March gave best rooting response. These results may be due to the physiological status of stock plants, cuttings taken at two planting dates may differ in the content of endogenous auxin (Davies, 1984, Wilson and Van Staden, 1990), rooting cofactors (El-Nabaway et al. 1983 and El-Torky and El-Shennawy, 1993), growth inhibitor (Souidan et al., 1995), and carbohydrates status which changed through a year by the activity of hydrolyzing enzymes (Zarad and Salah, 1994), which lead to different ability of cuttings to root.

The results in Table (1) also showed that wounding cuttings caused a significant increase in rooting percentage. These results were in agreement with Remmick and Bilderback (1993) on terminal cuttings of Illicium parviflorum, Ilex X $\square$ Nellie, Juniperus horizontalis and Photinia X fraser, Rosier (2003) on Fraser fir and with Ucler et al. (2004) on Actinidia deliciosa. Basal wounding is beneficial for rooting stem cuttings of several species especially when cuttings are collected from older material (Hartmann et al. 2002). Many researchers believe that wounding affects due to enhanced water, or auxin uptake through the extra wounded points (Nahlawi, 1974; Howard and Ridout, 1992) others think that by disrupting tissues that may depress root formation, rooting is increased (Beakbane, 1969). Others suggested that wounded tissues increased cell division which eventually gives rise to the formation of root primordial. This is due to natural accumulation of auxins and carbohydrates in the wounded area and to an increase in the respiration rate. In addition, injured tissues produce ethylene, which may indirectly promote root formation, also, there is an increase in ascorbic acid, fatty acid, lipids, phenolics and terpenoids in wounded area (Mackenzie et al. 1986; Hartmann et al. 2002). The suggested causes of the role of wounding on rooting ability may be explain the results in Table $(2,4,5)$ when interacts with other factors studied.

The significantly increase of rooting percentage and other characters studied of rooted cuttings when treated with IBA+NAA mixture Table $(1,3,4,5)$, may be explained by the roles of auxins in promoting cell division and enlargement then initiation of the root primordial (Hartmann et al. 2002), and 
the cuttings content of auxin and growth inhibitor, so the addition of exogenous auxin to cutting leakage of convenient level of endogenous auxin promote rooting ability (El-Nabawy et al., 1983; Souidan et al., 1995). Treatment cuttings by synthetic auxin caused to accumulate soluble sugar and other transported substances (co-factors, Nitrogenous substance and others) at base of cutting, more over the role of auxin in promoting the action of hydrolyzing enzymes (Nanda and Anand 1970; Molnar and Lacroix 1972). Hartmann et al. (2002) classified the plant rooting response to growth regulator to Easy-to-Root plants that have all the essential endogenous substances (root morphogens) plus auxin. When cutting are made and placed under proper environmental conditions, rapid root formation occurs, auxin may further enhance rooting, but generally not required. Then the benefit of auxin treatment as reported by Blazich (1988) to hastening root initiation, increasing the number and quality of roots produced per cutting, and increasing the uniformity of rooting. The plant under experimental conditions may be classified as shy to root plants because rooting percentage was not exceed from $86.67 \%$ (Table5), in spite of all the treatments studied. The cuttings remain in propagation beds for 22 weeks, because of the cuttings showed slow rooting process, when checked after 12 weeks no cuttings were rooted for two planting dates studied, but with time rooting was increased, this results was confirmed by Hartmann et al. (2002) that cuttings of some species required a longer time for rooting, so more experiments may be needed to enhanced early rooting of cuttings or grafted cuttings.

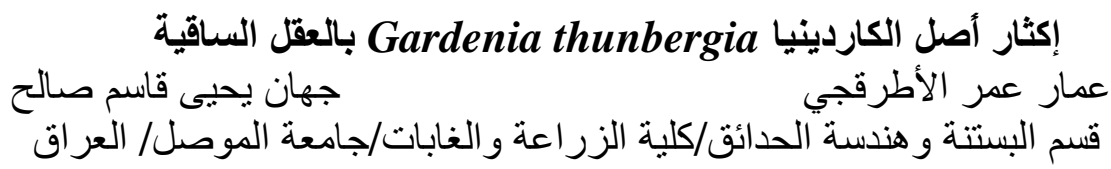

\section{الخلاصة}

أجريت الدراسة في البيت الزجاجي التابع لقسم البستنة وهندسة الحدائق/كلية الزراعة

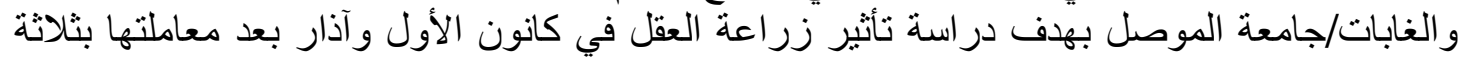

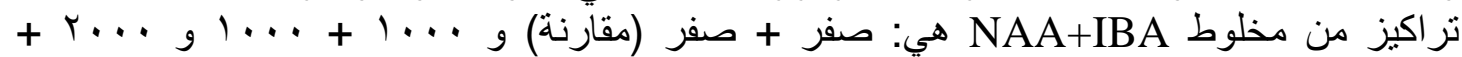

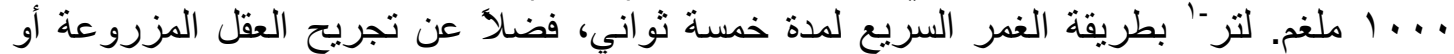

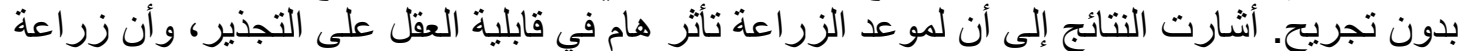

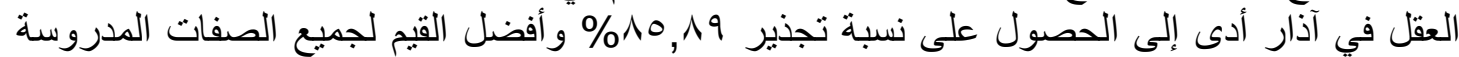

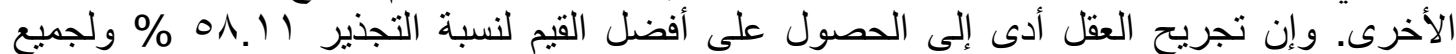

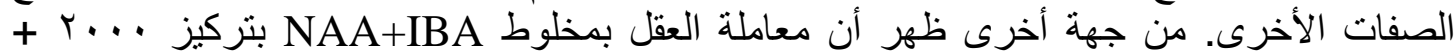

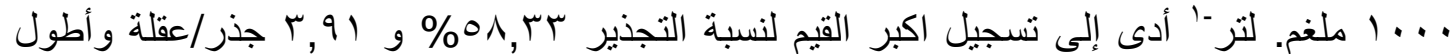

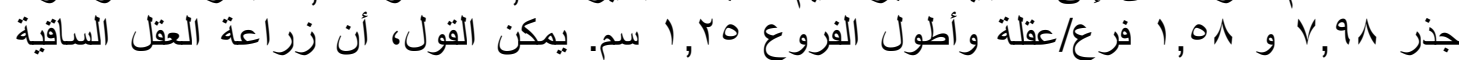

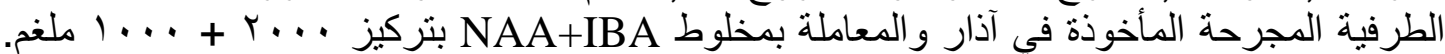

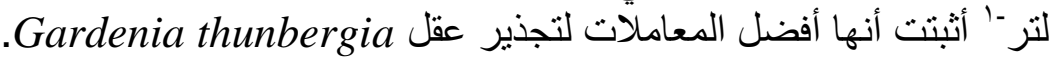

\section{REFERENCES}

Al- Atrakchii, A. O. (1998).Effect of cutting diameter, wounding and Naphthalene acetic acid on rooting of hardwood cuttings of Syringa vulgaris firmament. Mesoptemia J. Agric. 30(3):23-28. (In Arabic) 
AL-baili, S. A. (1967). The Garden. $1^{\text {st }}$ ed., Aledara Almahalea, Baghdad, Iraq (In Arabic).

Al-Noaimy, G. Y. Q. (1999). Study on propagation of Cotoneaster prostrate shrubs by terminal cuttings. M.SC. Thesis, College of Agric. and Forestry, Mosul University (In Arabic).

Anand, V. K. and G. T. Heberlein (1975). Seasonal changes in the effects of auxin on rooting in stem cuttings of Ficus infectoria. Physiol. plant. 34:330-334.

Bailey, L. H. (1969). Manual of Cultivated Plants, printed in the United States of America, Eleventh Printing.

Beakbane, A. B. (1969). Relationship between structures and adventitious rooting. Proc. 1nt. Plant prop. Soc. 19: 192-201.

Blazich, F. A. (1988). Chemical and Formulations Used to Promote Adventitious Rooting, In: Davis, T. D., B. E. Haissig and N. Sankhla N, (eds.). Adventitious Root Formation in Cuttings. Dioscorides Press, Portland, Ore. pp. 132-149.

Blythe, E. K.; J. L. Sibley; J. M. Ruter and K. M. Tilt (2004). Cutting propagation of foliage crops using a foliar application of auxin. Scientia Hort. 103(1): 31-37.

Bradshaw, J. (2003). Gardenias. University of Florida, IFAS Extension, CIR 1098:1-7.

Davies, F. T. Jr. (1984). Shoot RNA, cambial activity and indole butyric acid effectively in seasonal rooting of juvenile and mature Ficus pumila cuttings. Physiol. Plant. 62: 571-575.

EL. Torky, M. G. M. and O. A. EL-Shennawy (1993). Effect of indole butyric acid and propagation time on the rooting Ficus deltoidea and Euphorbia pulcherrima cuttings. Alex. J. Agric. Ros. 38(1): 283-304.

EL-Nabawy, S.; A. Bondok and I. S. EL-Din (1983). Studies on some factors affecting rooting in olive leafy cuttings. Annals Agric. Sci. 28(3) 16491669.

Hartmann, H. T., D. E. Kester, F. T. Davis, Jr., and R. L. Geneve (2002). Plant Propagation: Principles and Practices $7^{\text {th }}$ ed. Prentice Hall, Upper Saddle River, N. J.

Howard, B. H. and M. S. Ridout (1992). A mechanism to explain increased rooting in leafy cuttings of Syringa vulgaris "Madame Lemoine" following dark treatment of the stock plant. J. Hort. Sci. 59: 131-139.

Kobayashi, K. D. and A. J. Kaufman (2006). Common Gardenia. CTAHR, Univ. of Hawaii, Ornamentals and flowers, May, oF-32:1-7.

Mackenzie, K.D., B.H. Howard, and R.S. Harrison. Murray (1986). The anatomical relationship between cambial regeneration and root initiation in wounded winter cuttings of the apple root stock. M. 26. Annal Bot. 58:649-61.

Mastalerz, J.W.(1977). The Greenhouse Environment. John Wiley and Sons. pp.629 USA

Molnar, J. M. and L. J. Lacroix (1972). Studies of the rooting of cutting of Hydrangea macrophlla: enzyme changes. Can. J. of Botany 50: 315-22. 
Nahlawi, N. (1970). Effect of dipping depth and duration of auxin treatment an the rooting of cuttings. Comb. Proc. 1nt. Plant prop. Soc. 20: 292-300.

Nanda, K. K. and U. K. Anand (1974). Seasonal changes auxin effects on rooting of stem cutting of Populus nigra and its relationship with mobilization of starch. Physiol. Plant. 23: 99-107.

Remmick, M. D. and T. E. Bilderback (1993).Split wounding of stem cuttings. SNA Research Confernce.38: 289-291.

Rosier, C. L. (2003). Factors affecting the rooting of Fraser fir Abies fraseri and Virginia pine Pinus virginiana stem cutting. M.Sc. Thesis, N.C. State Univ. Raleigh.

Ruchala, S. L. (2002).Propagation of several native ornamental plants. M.Sc. Thesis, Univ. of Maine.

Ruppert, K. C. and J. Bradshaw (1994). Gardenias. Univ. of Florida Circular 1098:1-6.

Salman, M. A. (1988). Propagation of Horticulture Plants. Dar Alkotob Publishing Pressing, Mosul, Univ. Iraq. (In Arabic).

SAS (1996). Statistical Analysis System. SAS institute Inc., Cary, NC. USA.

Souidan, A. A.; M. M. Zayed and M. T. A. Dessouky (1995). A study on improving the rooting of Ficus elastica var. decora stem cuttings. 1. the effect of some auxinic treatments. Annals Agric. Sci. 40(2): 821-29.

Ucler, A. O., S. Parlak and Z. Yucesan (2004). Effects of IBA and cutting dates on the rooting ability of semi-hardwood kiwifruit Actinidia deliciosa A. chev. cuttings. Turk. J. Agric For 28:195-210.

Wells, J. S. (1962). Wounding cuttings as a commercial practice. Comb. Proc. Int. Plant Prop. Soc. 12: 47-54.

Wilson, P. J. and J. Van Staden (1990). Rhizocaline, rooting co-factors, and the concept of promoters and inhibitors of adventitious rooting, a review. Annals Bot. 66: 476-90.

Zarad, S. S. and M. A. Saleh (1994). Response of coffee stem cuttings to different auxin treatments in spring and fall season, Annals Agric. Sci. 39(2): 771-780. 